\title{
Religiusitas dan Perilaku Disiplin Santriwati Madrasah Aliyah Pondok Pesantren
}

\author{
Khusnul Khotimah \\ Universitas Islam Negeri (UIN) Antasari Banjarmasin
}

\begin{abstract}
The purpose of the study was to prove relationship religiosity to discipline behavior in a student at Islamic boarding schools. Student noncompliance with regulation indicates a lack of disciplinary behavior. So student needs to increase the value of religiosity in Islamic boarding school as a behavior controllers, one of which disciplined behavior. Correlational research type with a quantitative approach. Sample populations of student class XI and using random sampling with 68 samples. Research data collected using the religiosity scale and discipline behavior consisting of 26 and 27 items valid with a reliability coefficient of 0,700 and 0,787. The result of the study indicates that there is a positive relationship between religiosity and the behavior of student discipline, which means the higher the religiosity, the more positive the discipline behavior with the correlation coefficient rxy=0,328; $p=0,000$ $(p<0,01) . R$ square obtained by 0,108 , meaning that religiosity effectively contributes to $10,8 \%$ for discipline behavior.
\end{abstract}

Keyword: Religiosity; Discipline; Student; Islamic boarding schools

\begin{abstract}
Abstrak
Tujuan penelitian ialah membuktikan hubungan religiusitas terhadap perilaku disiplin pada santriwati Madrasah Aliyah di pondok pesantren. Ketidakpatuhan santriwati pada peraturan, mengindikasikan kurangnya perilaku disiplin, sehingga santriwati perlu meningkatkan nilai-nilai religiusitas yang di ajarkan di pondok pesantren sebagai pengontrol perilaku yang di lakukan, salah satunya perilaku disiplin. Jenis penelitian korelasional dengan pendekatan kuantitatif. Populasi sampel santriwati kelas XI dan menggunakan random sampling dengan jumlah 68 sampel. Data penelitian di kumpulkan menggunakan skala religiusitas dan perilaku disiplin dari 26 item dan 27 item valid dengan koefisien reliabilitas sebesar 0,700 dan 0,787 . Hasil penelitian menunjukkan bahwa terdapat hubungan positif antara religusitas dengan perilaku disiplin santriwati artinya semakin tinggi religiusitas maka semakin positif perilaku disiplin dengan koefisien korelasi $\mathrm{r}_{x y}=0,328 ; \mathrm{p}=0,000 \quad(\mathrm{p}<0,01)$. $\mathrm{R}$ square yang diperoleh sebesar 0,108 artinya religiusitas memberi sumbangan efektif sebesar 10,8\% terhadap perilaku disiplin.
\end{abstract}

Kata kunci: Religiusitas; Perilaku Disiplin; Santriwati; Pondok Pesantren

Pendidikan di Indonesia menjadi tolak ukur kemajuan suatu bangsa, pendidikan memiliki peranan penting untuk meningkatkan kualitas manusia yang baik, serta dapat mengembangkan potensi diri untuk menjadikan manusia yang berbudi pekerti, bermartabat 
dan memiliki keterampilan yang di perlukan oleh manusia dalam kehidupan bermasyarakat. Oleh karena itu membentuk perilaku yang baik diperlukan pendidikan agama yang berdasarkan Alquran dan hadist, agar mempunyai akhlak mulia serta berbudi pekerti yang baik lagi luhur.

Sebagaimana dalam undang-undang sistem pendidikan no 20 tahun 2003 pasal 30 ayat 02 menyatakan bahwa: pendidikan keagamaan berfungsi mempersiapkan peserta didik menjadi anggota masyarakat yang memahami dan mengamalkan nilai-nilai ajaran agamanya dan/atau menjadi ahli ilmu agama (UUD 1945). Oleh karena itu pendidikan berbasiskan agama sangat diperlukan, untuk mendapatkan pendidikan berbasiskan agama salah satunya dapat diperoleh di Pondok Pesantren. Pondok Pesantren memiliki karakteristik yang khusus dalam sistem pendidikannya yang mampu membentuk santri/santriwati yang berkualitas baik dari segi pengetahuan tentang agama serta mengaplikasikan pengetahuan tersebut dalam kesehariannya.

Mengingat bahwa santri/santriwati yang tinggal di lingkungan pesantren pada umumnya berusia 13 sampai 21 tahun yang mana termasuk pada fase atau masa remaja. Pada masa ini emosi dan sosial masih belum matang, masih memerlukan waktu untuk berkembang menjadi dewasa, kecerdasan yang dimiliki pun sedang mengalami proses pertumbuhan (Darajat, 2005). Oleh karena itu pada masa remaja ini diperlukan adaya pengawasan serta pengontrolah perilaku yang akan dimunculkan. Begitu pula dengan remaja yang tinggal di lingkungan Pondok Pesantren, pengawasan serta arahan tetaplah harus dilakukan seperti pembuatan peraturan dan tata tertib yang harus dipatuhi dan dilaksanakan agar terbentuknya perilaku disiplin dalam diri santri/santriwati. Istilah disiplin berasal dari bahasa Latin disciplina yang menunjuk kepada kegiatan belajar dan mengajar, istilah tersebut sangat dekat dengan istilah dalam bahasa Inggris disciple yang berarti mengikuti orang untuk belajar di bawah pengawasan seorang pemimpin. Dalam kegiatan belajar tersebut, bawahan dilatih untuk patuh dan taat pada peraturan-peraturan yang dibuat pemimpin (Tu'u,2008).

Sedangkan Menurut Soegeng Prijodarminto, disiplin sebagai kondisi yang terbentuk melalui proses dari serangkaian perilaku yang menunjukan nilai-nilai ketaatan, kepatuhan, kesetiaan, keteraturan atau ketertiban. Nilai-nilai tersebut telah menjadi bagian dari hidupnya. 
Perilaku tersebut tercipta melalui proses pembinaan keluarga, pendidikan, dan pengalaman atau pengenalan dari keteladanan dari lingkungannya (Soegeng, 2009). Adapun konsep disiplin menurut Hurlock, konsep populer daridisiplin adalah sama dengan hukuman. Menurut konsep ini disiplin digunakan hanya bila anak melanggar peraturan dan perintah yang diberikan orang tua, guru, atau orang dewasa yang berwenang mengatur kehidupan bermasyarakat di lingkungan tempat tinggal sekitar (Hurlock, 1978). Disiplin yang ketat membuat santriwati kurang mampu mentaati peraturan disiplin dikarenakan merasa tertekan sehingga diperlukan pengontrolan untuk mengimbangi perilaku yang akan dimunculkan yaitu religiusitas.

Sejalan dengan pendapat Darajat dalam Azizah (2016), bahwa dengan religiusitas yang baik niscaya individu tersebut akan lebih mendekatkan diri kepada Allah dan akan mendapatkan ketenangan hidup lahir dan batin serta dapat mengontrol perilakunya. Menurut Jalaluddin dalam Nadzir (2013) mengatakan bahwa religiustas adalah suatu keadaan dalam diri individu yang mendorong untuk bertingkah laku dalam kehiduan sehari-hari sesuai dengan kadar ketaatan nya terhadap agama. Menurut Ancok religiusitas dengan istilah keberagamaan yang diwujudkan dalam berbagai kehidupan manusia, baik itu menyangkut perilaku ritual beribadah atau aktivitas yang lain dalam kehidupannya yang di warnai dengan nuansa agama. Bukan hanya yang berhubungan dengan aktivitas yang tampak dilihat mata, tapi juga aktivitas yang tidak tampak dan hanya terjadi dalam hati seseorang (Ancok, 2011).

Pesantren memiliki metode dalam mengajarkan dan menerapkan praktik ibadah untuk mengembangkan reliugisitas santri. Praktik ibadah membawa manfaat secara psikologis bagi individu bila dilakukan penghayatan yang ditujukan kepada Allah SWT (Amir \& Lesnawati, 2016). Reliugisitas memiliki lima dimensi, yaitu: dimensi-dimensi religiusitas meliputi lima hal yaitu: keyakinan, peribadatan, pengalaman, pengetahuan agama, dan pengamalan (Ancok \& Suroso, 2011). Lima dimensi tersebut diajarkan pada santriwati yang belajar sekaligus tinggal di Pondok Pesantren.

Berdasarkan lima dimensi di atas maka agar para santriwati memiliki pemahaman agama yang baik, idealnya para santriwati memiliki penerapan perilaku disiplin sesuai dengan yang diajarkan atau didapatkan kemudian diaplikasikan ke dalam kehidupan sehari-hari salah satunya mentaati peraturan atau tata tertib yang berlaku. Seharusnya dengan memiliki 
religiusitas dan didasari pengetahuan agama yang cukup, maka secara tidak langsung santriwati yang seperti itu akan terhindar dari pelanggaran-pelanggaran dan dapat berperilaku disiplin.

Namun kenyataannya hal tersebut tidak sesuai dengan apa yang terjadi di lapangan, dari hasil pengamatan mengindikasikan adanya ketimpangan antara kenyataan dengan teori yang ada. Fenomena kurangnya perilaku disiplin santriwati di salah satu pondok pesantren $x$ di Banjarbaru, peneliti temukan melalui informasi dari ibu asrama dan staff OSIS yang mana dikatakan mereka bahwa ada saja dari santriwati menampakkan serangkaian perilaku yang cenderung mengindikasikan perilaku disiplin seperti mengikuti kegiatan gotong royong dengan baik, mematuhi peraturan yang berlaku, menjalankan aktivitas harian tanpa melanggar peraturan apapun.

Namun ada dari sebagian santriwati yang melakukan tindakan tidak disiplin seperti: tidak mengikuti kegiatan gotong royong, melanggar peraturan yang ada, membolos sekolah, makan di asrama, mengenakan seragam tidak sesuai dengan ketentuan dan tindakan lainnya yang tidak sesuai dengan aturan di Pondok Pesantren. Selain itu juga, santriwati menunjukan perilaku religiusitas yang ditampakkan melalui serangkaian perilaku ibadah dalam konteks agama Islam Seperti: pelaksanaan salat berjama'ah, zikir, membaca Alquran akan tetapi, dari hasil observasi masih terlihat santriwati yang cenderung kurang dalam pelaksanaan religiusitas dalam bentuk perilaku ibadah.

Dari permasalahan yang telah dipaparkan di atas maka dapat ditemukan pokok permasalahan serta tujuan penelitian ini adalah untuk membuktikan adanya hubungan antara religiusitas dengan perilaku disiplin santriwati di Pondok Pesantren X di Banjarbaru.

\section{Metode}

Jenis penelitian ialah kuantitatif korelasional. Penelitian ini dilaksanakan di salah satu pondok pesantren $X$ di Banjarbaru. Penelitian ini mengambil sampel santriwati tingkat aliyah yang tinggal di pondok pesantren sebagai subjek penelitian dengan jumlah 68 santriwati. Populasi penelitian berjumlah 136 santriwati. Variabel bebas penelitian ini adalah religiusitas dan variabel terikatnya adalah perilaku disiplin. Teknik pengambilan sampel yang digunakan 
adalah random sampling. Metode pengumpulan data dalam peneltian ini dengan menggunakan skala religiusitas dan skala perilaku disiplin. Skala religiuitas dan skala perilaku disiplin disusun dengan menggunakan model skala likert dengan empat alternatif jawaban, yaitu sangat setuju (SS), setuju (S), tidak setuju (TS), dan sangat tidak setuju (STS).

\section{Skala Religusitas}

Komponen religiusitas terdiri dari 26 item berdasarkan dimensi dimensi religiusitas dari Ancok (2011) yaitu dimensi keyakinan, praktik agama, pengalaman atau penghayatan, pengetahuan agama, dan pengamalan. Adapun dengan koefisien reliabilitas 0,700.

\section{Skala Perilaku Disiplin}

Komponen skala perilaku disiplin terdiri dari 27 item, skala ini merupakan kombinasi dari unsur-unsur disiplin menurut Hurlock dan aspek-aspek disiplin menurut Sogeng Prijodarminto yaitu hukuman, penghargaan, konsistensi, sikap mental (mental attitude), pemahaman yang baik tentang peraturan yang berlaku, dan kesungguhan dalam mentaati tata tertib. Adapun koefisien reliabilitas sebesar 0, 787

\section{Hasil}

Teknik analisis menggunakan analisis product moment dibantu dengan software Statictical Packages for Social Science (SPSS) 21.0 for Windows

Tabel 1

Uji hipotesis

\begin{tabular}{llrr}
\hline & \multicolumn{2}{c}{ Correlations } & \\
\hline & & Religiusitas & Perilaku disiplin \\
\multirow{4}{*}{ Religiusitas } & Pearson Correlation & 1 &, $328^{* *}$ \\
& Sig. (2-tailed) & &, 006 \\
& N & 68 & 68 \\
Perilakudisiplin & Pearson Correlation &, $328^{* *}$ & \\
& Sig. (2-tailed) &, 006 & 68 \\
\hline
\end{tabular}

**. Correlation is significant at the 0.01 level (2-tailed). 
Uji hipotesis menggunakan uji korelasi product moment dari Pearson. Berdasarkan hasil uji korelasi product moment bahwa ada hubungan positif antara religiusitas dengan perilaku disiplin yang tunjukkan oleh $\mathrm{p}=0,000$ atau $(\mathrm{p} \leq 0,01)$ dengan $\mathrm{rxy}=0,328$. Sehingga hipotesis dapat diterima, yaitu ada hubungan positif antara religiusitas dengan perilaku disiplin santriwati yang artinya semakin tinggi religiusitas seseorang maka semakin positif perilaku disiplin.

Tabel 2

Kategorisasi Religiusitas Santriwati

\section{Religiusitas}

\begin{tabular}{clcccc}
\hline & & Frequency & Percent & Valid Percent & $\begin{array}{c}\text { Cumulative } \\
\text { Percent }\end{array}$ \\
\hline \multirow{4}{*}{ Valid } & Tinggi & 12 & 17,6 & 17,6 & 17,6 \\
& Sedang & 49 & 72,1 & 72,1 & 89,7 \\
& Rendah & 7 & 10,3 & 10,3 & 100,0 \\
& Total & 68 & 100,0 & 100,0 & \\
\hline
\end{tabular}

Berdasarkan pengkategorian religiusitas santriwati dapat diketahui bahwa intensitas religiusitas santriwati dengan intensitas tinggi sebesar 17,6\%, intensitas sedang sebesar 72,1\% dan intensitas rendah sebesar 10,3\%. Jadi dapat dikatakan bahwa religiusitas santriwati secara umum berada pada kategori sedang.

Tabel 3

Kategorisasi Perilaku Disiplin

Perilaku Disiplin

\begin{tabular}{rlrrrr}
\hline & \multicolumn{1}{c}{ F } & \multicolumn{1}{c}{$\%$} & Valid Percent & Cumulative Percent \\
\hline \multirow{4}{*}{ Valid } & Tinggi & 8 & 11,8 & 11,8 & 11,8 \\
& Sedang & 51 & 75,0 & 75,0 & 86,8 \\
& Rendah & 9 & 13,2 & 13,2 & 100,0 \\
& Total & 68 & 100,0 & 100,0 & \\
\hline
\end{tabular}

Berdasarkan kategori perilaku disiplin santriwati dapat diketahui bahwa intensitas perilaku disiplin santriwati dengan intensitas tinggi sebesar $11,8 \%$, intensitas sedang sebesar 
$75,0 \%$ dan intensitas rendah sebesar $13,2 \%$. Jadi kategori perilaku disiplin santriwati secara umum berada pada kategori sedang.

\section{Pembahasan}

Hasil analisis data skala religiusitas dan skala perilaku disiplin menunjukkan bahwa ada hubungan positif antara religiusitas dengan perilaku disiplin santriwati Madrasah Aliyah, berdasarkan hasil uji korelasi product moment yaitu $\mathrm{rxy}_{\mathrm{y}}=0,328 ; \mathrm{p}=0,000 \quad(\mathrm{p}<0,01)$ sehingga religiusitas dinyatakan memiliki hubungan positif terhadap perilaku disiplin dan $\mathrm{Ha}$ atau hipotesis kerja dapat diterima. Hubungan yang positif berarti semakin tinggi reliugisitas yang dimiliki santriawati maka semakin tinggi pula disiplin yang dimiliki oleh santriawati aliyah.

Seseorang dengan tingkat religiusitas yang baik adalah mereka yang mampu mengaplikasikan keyakinan, pemahaman tentang agama, pegalaman, pengamalan serta ibadah dalam kehidupan sehari-hari dengan kesungguhan hati. Sesuai dengan teori religiusitas menurut Glock dan Stark yang mengatakan bahwa religiusitas atau keberagamaan dalam Islam bukan hanya diwujudkan dalam bentuk ibadah ritual saja, tapi juga dalam aktivitas-aktivitas lainnya(Ancok, 2011).

Sebagai suatu sistem yang menyeluruh (Ancok, 2011). Dengan pengamalan agama yang baik dapat mengontrol perilaku yang ditampilkan sesuai dengan norma sosial, tata tertib yang berlaku di lingkungan sekitar salah satunya perilaku disiplin. Sejalan dengan pendapat Darajat dalam Nur, bahwa dengan religiusitas yang baik niscaya individu tersebut akan lebih mendekatkan diri kepada Allah SWT dan akan mendapatkan ketenangan hidup lahir dan batin serta dapat mengontrol perilakunya (Azizah, 2016).

Menurut Soegeng Prijodarminto, disiplin sebagai kondisi yang terbentuk melalui proses dari serangkaian perilaku yang menunjukan nilai-nilai ketaatan, kepatuhan, kesetiaan, keteraturan atau ketetiban. Nilai-nilai tersebut telah menjadi bagian dari hidupnya (Tu'u, 2008). Perilaku disiplin merupakan ketaatan seseorang pada peraturan yang telah ditetapkan berdasarkan norma-norma yang ada. termasuk ketaatan seseorang terhadap agamanya seperti taat menjalankan perintah Allah SWT; melaksanakan salat tepat waktu, mengeluarkan zakat sesuai dengan aturannya, mematuhi norma-norma serta nilai-nilai yang berlaku dilingkungan 
sekitar, serta menjauhi larangan Nya; berbuat dzalim, menuruti hawa nafsu tanpa mengendalikannya termasuk perilaku pelanggaran-pelanggaran yang dilakukan di lingkungan pondok pesantren seperti: tidak mengikuti salat berjamaa'ah, meninggalkan salat wajib dan pelanggaran peraturan lainnya yang dilakukan santriwati di pondok pesantren.

Hubungan positif antara religiusitas terhadap perilaku disiplin santriwati Madrasah Aliah juga didukung oleh penelitian-penelitian sebelumnya. Seperti pada penelitian yang dilakukan oleh Ahmad dan Nawang, tentang hubungan antara religiusitas dengan penyesuaian diri siswa Pondok Pesantren menyatakan bahwa ada hubungan positif antara religiusitas dengan penyesuaian diri (Nadzir, 2013). Kemudian pada penelitian yang dilakukan oleh Deci dan Fajar tentang hubungan antara regulasi emosi dengan perilaku disiplin menunjukkan bahwa terdapat pengaruh regulasi emosi dengan perilaku disiplin (Deci \& Fajar, 2016). Peneliti melakukan riset dengan variabel yang berbeda dari penelitian sebelumnya. Hal ini dilakukan guna memperkaya integrasi keilmuan psikologi dan keislaman serta membuktikan ada hubungan antara variabel satu dengan variabel lain yang belum diteliti sebelumnya.

Pada hasil penelitian ini didapat pula angka sumbangan efektif atau besaran pengaruh variabel bebas terhadap variabel terkait yang ditandai oleh nilai $R^{2}$. Adapun nilai $R^{2}$ yang didapat ialah 10,8\% yang berarti religiusitas memberikan sumbangan efektif terhadap perilaku disiplin sebesar 10,8\%. Maka hal ini menunjukkan bahwa religiusitas sebagai variabel bebas memiliki peran dalam mempengaruhi religiusitas yang merupakan variabel terikat dalam penelitian ini. Sedangkan $89,2 \%$ dari $R^{2}$ dipengaruhi oleh variabel lain yang tidak terdapat dalam penelitian ini.

Adapun subjek penelitian yaitu santriwati Madrasah Aliah Pondok Pesantren Al-Falah Puteri dengan kisaran usia 17-21 tahun. Jersild dkk dalam Andi membicarakan remaja (adolescence) dalam rentang usia sebelas tahun sampai usia dua puluh-an awal, menyatakan bahwa masa remaja melingkupi periode atau masa bertumbuhnya seseorang dalam masa transisi dari masa kanak-kanak ke masa dewasa (Mappiare, 1998)

Pada masa ini emosi serta sosial masih belum matang, pada masa ini individu ingin berdiri sendiri serta keadaan jiwa agama pun belum stabil hingga tak jarang mengalamai 
kegoncanagan dan ketidakstabilan dalam beragama. Misalnya, kadang-kadang mereka tekun beribadah tapi pada waktu yang lain enggan melaksanakannya (Darajat, 2005). Seperti halnya yang dilakukan santriwati di pondok pesantren, terkadang mereka mematuhi aturan di pondok tetapi diwaktu yang lain juga melakukan pelanggaran dan menunjukkan sikap tidak disiplin.

Hasil kategori tingkatan religiusitas maupun perilaku disiplin dalam penelitian ini menunjukkan tingkatan religiusitas dan perilaku disiplin lebih dominan pada kategori sedang. Karena jumlah responden yang berada pada kategori sedang lebih banyak daripada responden yang berada pada kategori tinggi dan rendah, yaitu, 75\% untuk perilaku disiplin dan 72,1\% untuk religiusitas. Secara tidak langsung kategori ini menjelaskan bahwa jumlah santriwati dengan perilaku disiplin rendah tidak dominan.

Berdasarkan aspek perilaku disiplin salah satunya adalah adanya hukuman bagi santriwati yang melakukan pelanggaran. Berdasarkan observasi dan wawancara yang dilakukan peneliti sebagai studi pendahuluan terhadap staff HPPA/OSIS di Pondok Pesantren Al-Falah Puteri Banjarbaru menyatakan bahwa santriwati sering melakukan pelanggaranpelanggaran peraturan seperti terlambat memasuki kelas, tidak menggenakan seragam yang sesuai, tidak mengikuti kegiatan belajar dikelas, membawa elektronik di kelas, terlambat memasuki musholla, tidak sholat berjama'ah dan pelanggaran lainnya.

Berdasarkan hasil wawancara dengan salah satu pengurus pesantren, santriwati melakukan pelanggaran peraturan hampir pada setiap minggunya, karena pada hari Jum'at staff HPPA memanggil santriwati yang melanggar peraturan serta memberikan sanksi kepada santriwati yang melanggar tersebut dan pernah jumlah santriwati yang dipanggil lebih dari 60 orang dari 120 santriwati terdiri dari 4 kelas dikarenakan melakukan keributan di kelas dan sering berdiri di luar kelas ketika jam pelajaran kosong.

Santriwati melakukan pelanggaran peraturan akan mendapatkan sanksi atau hukuman yang nantinya memberikan efek jera bagi santriwati. Sesuai pendapat Hurlock yang menyatakan hukuman digunakan agar tidak mengulangi perilaku yang salah dikemudian hari (Hurlock, 1978).

Berdasarkan hasil wawancara dengan informan yang merupakan salah satu ibu asrama diperoleh keterangan lebih lanjut mengenai pelanggaran yang dilakukan santriwati di asrama 
ibu asrama yang menyatakan bahwa: “ada saja santriwati yang melanggar perturan asrama yang telah ditetapkan seperti pulang melebihi batas yang telah ditetapkan, tidak piket, ribut, berkelahi, membuang sampah sembarangan dan sebagainya". Hal tersebut sesuai dengan pendapat Gunarsa dalam Zulva mengatakan bahwa pelanggaran-pelanggaran kedisiplinan di lingkungan sekolah antara lain keterlambatan, membolos, perkelahian, dan menyontek (Pujawati, 2016).

Dari hasil wawancara menyatakan bahwa pada tiap minggu nya masih saja ada santriwati yang melakukan pelanggaran dan mendapat hukuman sebagai efek jera. Sehingga sesuai dengan pernyataan Hurlock bahwa konsep disiplin sama dengan hukuman (Hurlock, 1978).

\section{Kesimpulan}

Terdapat hubungan posistif antara religusitas dengan perilaku disiplin santriwati Madrasah Aliyah Pondok Pesantren X di Banjarbaru dengan nilai koefisien korelasi $\mathrm{r}_{\mathrm{xy}}=0,328$; $\mathrm{p}=0,000(\mathrm{p}<0,01)$ atau dengan kata lain semakin tinggi reliugisitas maka semakin tinggi pula disiplin santriwati. Berdasarkan nilai R Square religiusitas memberi sumbangan efektif sebesar 0, 108 atau 10,8 \% terhadap perilaku disiplin santriwati. Berdasarkan hasil uji pengsskategorian menyatakan bahwa tingkat religiusitas santriwati Madrasah Aliah Pondok Pesantren x di Banjabaru. Secara umum religiusitas santriwati termasuk kedalam kategori sedang yaitu sekitar 75,0\%. Dan pengkategorian dari tingkat perilaku disiplin santriwati Madrasah Aliah Pondok Pesantren secara umum termasuk dalam kategori sedang yaitu sebesar 72,1\%. Sehingga hal tersebut menjelaskan bahwa tingkat religiusitas menjadi salah satu sebab rendah, sedang atau tingginya dari perilaku disiplin santriwati.

\section{Saran}

Untuk penelitian selanjutnya agar lebih memperhatikan faktor-faktor atau aspek-aspek dari religiusitas pada subjek yang akan di teliti, agar peneliti selanjutnya benar-benar yakin dan mengetahui bahwa religiusitas memiliki pengaruh yang besar terhadap variabel yang digunakan. Menggunakan jumlah sampel dengan jumlah yang lebih besardan variatif agar mendapatkan gambaran yang lebih lengkap mengenai religiusitas dan perilaku disiplin. Bagi 
para peneliti selanjutnya tidak hanya melakukan wawancara sebagai studi pendahuluan, namun melakukan observasi mendalam terhadap subjek yang diteliti sehingga latar belakang masalah lebih jelas dan kuat. Dan memodifikasi alat ukur yang sudah ada agar memiliki nilai validitas dan reliabilitas yang lebih tinggi.

\section{Referensi}

Amir, Y. \& Lesnawati, D. R. ( 2016) Religiusitas dan spiritualitas: Konsep yang sama atau berbeda?, Jurnal Ilmiah Penelitian Psikologi: Kajian Empiris dan Non empiris, 2(2).

Mappiare, A. (1998) Psikologi remaja. Surabaya: Usaha Nasional.

Ancok, D. \& Nashori, F. (2011) Psikologi Islami : Solusi Islam Atas Problem-Problem Psikologi, Yogyakarta: Pustaka Pelajar.

Azizah, N. (2016) Perilaku moral dan religiusitas siswa berlatar belakang pendidikan umum dan agama. Jurnal Psikologi, 33(2),

Darajat, Z. (2005) Ilmu jiwa agama. Jakarta: Bulan Bintang.

Hurlock, E. B. (1978) Perkembangan anak. terj. Meitasari Tjandrasa. Jakarta: Erlangga.

Nadzir, A. I. \& Wulandari, N. W. (2013) Hubungan religiusitas dengan penyesuaian diri siswa pondok pesantren. Jurnal Psikologi Tabularasa, 8(2).

Nansi, D. \& Utami, F. T. (2016) Hubungan antara regulasi emosi dengan perilaku disiplin santri madrasah aliah pondok pesantren Qadratullah Langkan. Jurnal Psikologi Islami,2(1).

Prijodarminto, S. (2009) Disiplin Kiat Menuju Sukses. Jakarta: Pradnya Paramita.

Pujawati, Z. (2016) Hubungan kontrol diri dan dukungan orang tua dan perilaku disiplin pada santriwati di pondok pesantren Daruss'adah Samarinda. Jurnal Psikologi, 4(2).

Republik Indonesia, Memahami Undang-Undang, Menumbuhkan Kesadaran, 10.

Tu'u, T. (2008) Peran disiplin pada perilaku dan prestasi siswa, Jakarta: PT Grasindo. 